УДК

Старинецьв М.О., Очередько О.М.

\title{
Обгрунтування та ідентифікація моделей оцінки ефекту програм профілактики розвитку спазму акомодації
}

\author{
Вінницький національний медичний університет ім. М.І. Пирогова, м. Вінниця, Україна
}

\begin{abstract}
Мета - обгрунтування та ідентифікація моделей оцінки ефекту програм профілактики розвитку спазму акомодації на базі сучасних аналітичних методів та дизайнів.

Матеріали іметоди. Матеріалами стали розроблені нами програми дослідження, загальний обсяг вибірки склав 1115 школярів. Використаний панельний гніздований блоковий дизайн. Серійним методом вивчені первинні випадки виникнення порушень акомодації у школярів разом з медико-організачійними та популяційними обумовлюючими факторами протягом 2014-2018 років за участі в стандартній і розширеній програмах профілактики. Аналітичні методи охоплювали семи-параметричну модель Кокса, фрейлті модель, фрейлті модель з фракцією нечутливих.

Результати засвідчили про відсутність прошарку школярів, нечутливих до розвитку спазму акомодації (СА). Інша ідентифікація форми включала індивідуальний розподіл чутливості (фрейлті модель), щчо однозначно підтримано даними. Отюе, підтримується гіпотеза щеодо наявності індивідуальної чутливості до розвитку СА і наступної міопї. Встановлено, щзо участь у програмі профілактики (ПП) суттєво зменшує ризик виникнення СА незалежно від присутності набутої чутливості (факторів ризику) та вродженої (фрейлті). Висновок робастний за трьома моделями. Тому ПП дочільна для призначення кожному школяреві беззастережно шчодо індивідуальних ознак. Середнє річне зменшення ризиків СА внаслідок участі у ПП за різними моделями складало 3,75\%, 2,50\%, та 4,08\%. Причому ефект відтворений незалежно від моменту початку участі у ПП.
\end{abstract}

\section{Вступ}

$\mathrm{O}$ цінка ефективностті ПП розвитку спазму акомодації утруднена великим і мінливим латентним періодом, супутніми впливовими факторами, кластеризацією школярів по школам, класам, викладачам. Проведено обгрунтування та ідентифікація моделей оцінки ефекту програм профілактики ризику розвитку СА. Розширена програма включала засоби підвищення комплаянсу через моніторинг, залучення психолога до бесід з батьками. Розширена програма призначалась рандомізовано, проте за згодою батьків.

\section{Матеріали та методи}

Оцінка ефективності за експериментальним фреймом може бути зміщеною через скошеність призначення виду програми профілактики (СПЕ ефект), а також внаслідок змішувального ефекту множини факторів, рівні яких не контролюються дизайном, ба навіть невідомі.

Тому поряд 3 базовою семи-параметричною моделлю виживання ми застосували фрейлті модель, а також, зважаючи на можливість існування нереспонсивних дітей фрейлті модель 3 фракцією нечутливих.

Базова модель.

Вид моделі задається характером виміру ефекту i функцією зв'язку $\mathrm{y}=\mathrm{f}(w \mid \theta, \mathbf{x})$. У нашому випадку ефект представлений проміжками часу із подіями, якими $є$ виникнення СА, тобто маємо класичні умови моделі виживання. Специфікація моделі залежить від виду гіпотези, організації даних, та розподілу проміжків часу до виникнення події (залежної змінної).

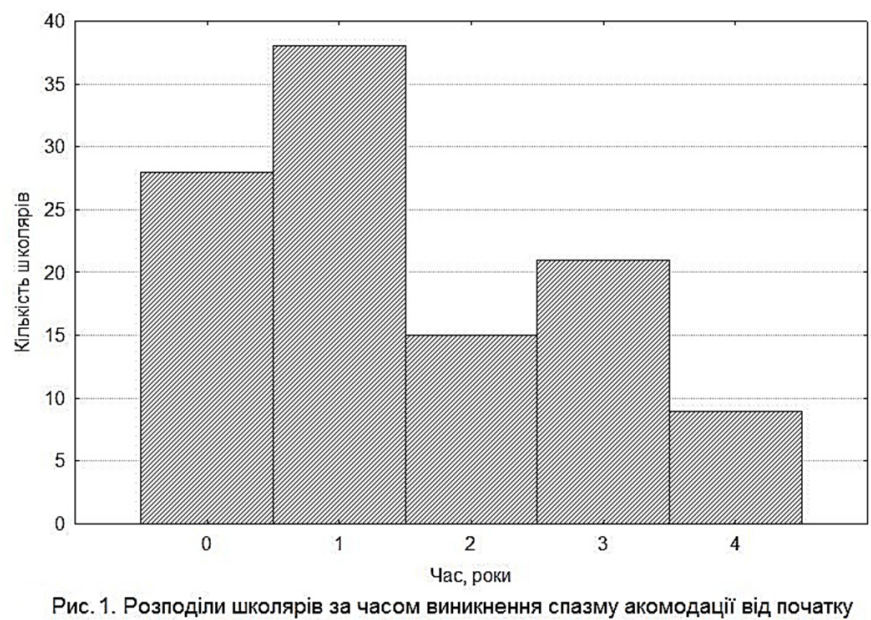
спостереження

Очевидно, що розподіл має унімодальний характер 3 вираженою модою, що приходиться на перший рік спостереження (рис. 1). Така форма розподілу зручно описується лог-логістичною (log-logistic) та серповидною (sickle) моделями відповідно до назв щільностей розподілів [1]. Обидва розподіли мають схожу форму і однакову кількість параметрів із співзвучним значенням. Ми використали лог-логістичний розподіл. В проекції моделі виживання ми маємо аналітично задати функцію ризику, що типово позначається $h(t)$, і функцію виживання $S(t)$. За лог-логістичного розподілу ці функції виражені як [2]: 


$$
\begin{aligned}
& \boldsymbol{h}(\boldsymbol{t})=\lambda \kappa \boldsymbol{t}^{\kappa-1}\left[1+\lambda \boldsymbol{t}^{\kappa}\right]^{-1} \\
& \boldsymbol{S}(\boldsymbol{t})=\left[1+\lambda \boldsymbol{t}^{\kappa}\right]^{-1}
\end{aligned}
$$

$t$ - часовий проміжок;

$\boldsymbol{\kappa}$ - параметр форми розподілу;

$\lambda$ - середнє значення розподілу.

На цих виразах зупинимось детальніше, так як це важливо для наступної інтерпретації результатів. По-перше, функція ризику вказує на вірогідність виникнення СА в момент $t$, тоді як функція виживання оцінює вірогідність дожити до момента часу $t$ без виникнення цих подій. По-друге, очевидний нелінійний характер зміни цих функцій в часі з наявним піком. По-

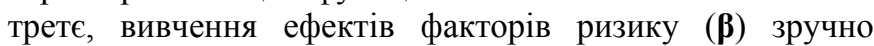
здійснювати через їх вплив на середне (очікуване) значення розподілу $\lambda$. Зважаючи на мультиплікативне включення $\lambda$ в ф. 1, а також аддитивний характер лінійного предиктору (ЛП), використовується лог-функція зв'язку, a саме:

$$
\log \lambda=\beta_{0}+\beta_{1} x_{1}+\ldots+\beta_{p} x_{p}
$$

3 ф.1 видно, що більші значення $\lambda$ свідчать про більший очікуваний ризик $h(t)$, і відповідно менші очікувані значення $S(t)$, тобто менші шанси до збереження нормального зору до часу $t$. Відповідно негативні значення регресійних ефектів $\beta_{\mathrm{k}}$ свідчать про зменшення ризику розвитку СА (протективна дія відповідного фактору х⿱ $\mathrm{x}_{\mathrm{k}}$ ), $\mathrm{i}$ навпаки, позитивні значення регресійних ефектів $\beta_{\mathrm{k}}$ свідчать про збільшення ризику розвитку СА фактором $\mathrm{x}_{\mathrm{k}}$ (фактор ризику).

Таким чином, логарифм функції правдоподібності базової моделі виглядає як:

$$
\log (\boldsymbol{L})=\sum_{i=1}^{N}\left[d(t)_{i} \log \left(f(t)_{i}\right)+\left(1-d(t)_{i}\right) \log S(t)_{i}\right]
$$

3 функцією розподілу $\boldsymbol{f}(\boldsymbol{t})_{\boldsymbol{i}}=\boldsymbol{h}(\boldsymbol{t})_{\boldsymbol{i}} \bullet \boldsymbol{S}(\boldsymbol{t}-1)_{\boldsymbol{i}}$ індикаторною змінною $\mathrm{d}(\mathrm{t})_{\mathrm{i}}=1$ при розвитку CA на момент часу $\mathrm{t}$, та $\mathrm{d}(\mathrm{t})_{\mathrm{i}}=0$ на закінченні спостереження в момент $\mathrm{t}$ без виникнення СА (право-цензурований проміжок).

Для змістовнішої інтерпретації ми скористалися поняттям модального часу, тобто часом найбільш вірогідного розвитку порушення зору з моменту початку спостереження. Модальний час $t$ залежить від характеристик школяра і відповідно до лог-логістичного розподілу визначається як (формула виведена нами, тому виведення наводиться):

$$
\begin{aligned}
& \frac{\partial \boldsymbol{h}(\boldsymbol{t})}{\partial \boldsymbol{t}}=0 \\
& \lambda \kappa \boldsymbol{t}^{\kappa-1} \bullet \frac{\partial\left[1+\lambda \boldsymbol{t}^{\kappa}\right]^{-1}}{\partial \boldsymbol{t}}+\frac{\partial \lambda \kappa \boldsymbol{t}^{\kappa-1}}{\partial \boldsymbol{t}} \bullet\left[1+\lambda \boldsymbol{t}^{\kappa}\right]^{-1}=0 \\
& \frac{\lambda \kappa \boldsymbol{t}^{\kappa-1}}{\left[1+\lambda \boldsymbol{t}^{\kappa}\right]^{2}} \bullet \frac{\partial \lambda \boldsymbol{t}^{\kappa}}{\partial \boldsymbol{t}}=\frac{\partial \lambda \kappa \boldsymbol{t}^{\kappa-1}}{\partial \boldsymbol{t}} \bullet\left[1+\lambda \boldsymbol{t}^{\kappa}\right]^{-1} \\
& \frac{\lambda \kappa \boldsymbol{t}^{\kappa-1}}{\left.1+\lambda \boldsymbol{t}^{\mathrm{\kappa}}\right]} \cdot \frac{\partial \lambda \boldsymbol{t}^{\kappa}}{\partial \boldsymbol{t}}=\frac{\partial \lambda \kappa \boldsymbol{t}^{\kappa-1}}{\partial \boldsymbol{t}} \\
& \boldsymbol{t}^{\kappa-1} \\
& {\left[1+\lambda \boldsymbol{t}^{\mathrm{\kappa}}\right]} \\
& \boldsymbol{t}^{\mathrm{\kappa}}=\frac{\kappa-1}{\kappa \lambda} \bullet\left(1+\lambda \boldsymbol{t}^{\mathrm{\kappa}}\right)=\frac{\kappa-1}{\kappa \lambda}+\frac{\kappa-1}{\kappa \lambda} \bullet \lambda \boldsymbol{t}^{\kappa} \\
& \boldsymbol{t}^{\kappa} \bullet\left(1-\frac{\kappa-1}{\kappa}\right)=\frac{\kappa-1}{\kappa \lambda} \\
& \boldsymbol{t}^{\kappa}=\frac{\kappa-1}{\lambda} \\
& \boldsymbol{t}=\{(\kappa-1) \bullet \exp (-\beta \boldsymbol{x})\}^{1 / \kappa}
\end{aligned}
$$

На основі ф.3 ми використаємо модальний час для унаочнення клінічного ефекту ПП для школярів з різними характеристиками.

Модель з фракиією нечутливих

$€$ багато свідчень генетичної детермінованості СА, а отже, наявності школярів, які мало чутливі або взагалі не чутливі до розвитку СА. Неврахування наявності фракції нечутливих серед контролю та основної групи призводить до зміщених (в сторону зменшення за модулем) оцінок ефектів факторів, зокрема ефекту програми профілактики (ПП). Саме тому ми наряду з базовою розглянули модель з фракиією нечутливих (cure rate model) до розвитку CA дітей як розширення базової [3].

Для інкорпорації фракції нечутливих ми використали оригінальний підхід, розроблений Ченом [4], за яким вся вибірка розподіляється за латентними групами «вродженого» ризику до розвитку $\mathrm{CA}\left(\mathrm{G}_{0}, \ldots, \mathrm{G}_{\mathrm{K}}\right)$, які розподілені на вибірці за законом Пуассона з середнім значенням розподілу $\theta$ і латентними проміжками часу $\left(\mathrm{T}_{0}, \ldots, \mathrm{T}_{\mathrm{K}}\right)$ реалізації ризиків в подію (виникнення $\mathrm{CA}$ ). Передбачається, що $\mathrm{T}_{0}, \ldots, \mathrm{T}_{\mathrm{K}}$ мають однаковий розподіл $F(t)$, пов'язаний з функцією виживання $S(t)$ як $F(t)=1-S(t)$. Безпосередній час події (рік чи клас реєстрації CA) $\epsilon$ мінімальним $3 \mathrm{~T}_{0}, \ldots, \mathrm{T}_{\mathrm{K}}$. Якщо це група $\mathrm{G}_{0}$, дитина не чутлива до розвитку СА. Користуючись розподілом Пуассона композитна функція виживання представлена як: 


$$
\begin{aligned}
& \boldsymbol{S}^{*}\left(\boldsymbol{t}_{\boldsymbol{i}}\right)=\operatorname{Pr}\left(\boldsymbol{G}_{\boldsymbol{i}}=0\right)+\operatorname{Pr}\left(\boldsymbol{T}_{\boldsymbol{i} 1}>\boldsymbol{t}_{\boldsymbol{i}}, \ldots, \boldsymbol{T}_{\boldsymbol{i} \boldsymbol{G} \boldsymbol{i}}>\boldsymbol{t}_{\boldsymbol{i}} \mid \boldsymbol{G}_{\boldsymbol{i}}>1\right), \\
& =\exp (-\theta)+\sum_{\boldsymbol{k}=1}^{\infty} \boldsymbol{S}(\boldsymbol{t})_{\boldsymbol{k}} \cdot \frac{\theta^{\boldsymbol{k}}}{\boldsymbol{k} !} \exp (-\theta) \\
& =\exp (-\theta+\theta \boldsymbol{S}(\boldsymbol{t}))=\exp (-\theta \boldsymbol{F}(\boldsymbol{t}))
\end{aligned}
$$

Відповідно композитна функція ризику

$$
\boldsymbol{h}^{*}\left(\boldsymbol{t}_{\boldsymbol{i}}\right)=\theta \boldsymbol{f}\left(\boldsymbol{t}_{\boldsymbol{i}}\right)
$$

Таким чином, логарифм функції правдоподібності моделі з фракцією нечутливих виглядає як:

$$
\log (\boldsymbol{L})=\sum_{i=1}^{N}\left[\boldsymbol{d}(\boldsymbol{t})_{i} \log \left(\boldsymbol{f}^{*}(\boldsymbol{t})_{i}\right)+\left(1-\boldsymbol{d}(\boldsymbol{t})_{i}\right) \log \boldsymbol{S}^{*}(\boldsymbol{t})_{i}\right]
$$

3 композитною функцією розподілу часу виникнення СА: $f^{*}(t)_{i}=h^{*}(t)_{i} \bullet S^{*}(t-1)_{i}$ та індикаторною змінною $\mathrm{d}(\mathrm{t})_{\mathrm{i}}=1$ при розвитку $\mathrm{CA}$ на момент часу $\mathrm{t}$, тa $\mathrm{d}(\mathrm{t})_{\mathrm{i}}=0$ при право-цензурованому проміжку.

\section{Фрейлті модель з фракиією нечутливих}

Крім необхідності врахування фракції нечутливих до розвитку СА дітей важливо також включити безпосередньо неспостерігаємі (латентні) індивідуальні чутливості до розвитку СА; [5]. Їх невключення супроводжується двома відомими зміщеннями: (i) завищену оцінку негативної часової залежності базового ризику і відповідно занижену оцінку позитивної часової залежності відповідних параметрів функції базового ризику $h_{0}(t)$. Вказане $\epsilon$ наслідком селекції внаслідок індивідуальної гетерогенності чутливості до виникнення СА. Так, при негативній часовій залежності ризику діти 3 високими значеннями фрейлті (високо чутливі до виникнення СА) швидше реалізують подію і покидають вибірку, таким чином склад вибірки 3 часом спостереження насичується дітьми з низькою чутливістю $\mathrm{i}$ відповідно штучно зниженими значеннями базового ризику (Lancaster, 1990). (ii) відомий також ефект зміщення (зменшення за модулем) ефектів факторів, що змінюють ризик [6]. Зважаючи на позитивність значень, ми використали лог-нормальний розподіл фрейлті $(\boldsymbol{u})$ аддитивно в ЛП моделі (2), а саме [7]:

$$
\begin{aligned}
\lambda_{i} & =\exp \left(\boldsymbol{\beta} \boldsymbol{x}_{\boldsymbol{i}}+\boldsymbol{u}_{\boldsymbol{i}}\right), \\
\boldsymbol{u}_{\boldsymbol{i}} & \sim \boldsymbol{N}\left(0,1 / \tau_{\boldsymbol{u}}\right)
\end{aligned}
$$$$
N\left(0,1 / \tau_{u}\right)
$$

де $\boldsymbol{N}\left(0,1 / \tau_{\boldsymbol{u}}\right)$ - нормальний закон розподілу індивідуального значення фрейлті 3 нульовим першим моментом і другим моментом $\mathfrak{u}^{-1}$.
Логарифм функції правдоподібності фрейлті моделі 3 фракцією нечутливих виглядає як ф.5 з різницею в ЛП ( $\lambda)$ та додатковим лог-нормальним розподілом фрейлті.

Статистична ідентифікація ефекту програми профілактики

Статистичне обгрунтування тестування ефективності ПП належить до сегменту технік аналізу даних під загальною назвою «Average treatment effect», АТЕ. Однією 3 основних проблем $є$ зміщення оцінки ефективності внаслідок порушення рандомізації призначення програми, зокрема ефекту self-selection.

Загальною канвою методик $є$ врахування безпосередньо неспостерігаємої гетерогенності, яка, зокрема, призводить до зміщеного тестування ефективності у разі іiі зв'язку із параметрами тесту, наприклад, розміщенням пацієнтів до основної i контрольної когорт.

Позначимо через $y$ показник ефективності впроваджень, а через вектор $w$ - складові впровадження. Нас цікавить ефект $w$ на $y$ в структурній моделі

$$
\mathrm{E}(y \mid w, \mathbf{c})=a+b w,
$$

де $\mathbf{c} \equiv(a, b)$ і $a$ та $b$ можуть залежати як від спостережених ковариат, так і неспостерігаємої гетерогенності (НГ).

Так як ефект $\epsilon$ рандомізованим, тобто $b$ не $\epsilon$ констаним внаслідок залежності від НГ, ми фактично оцінюємо середній парціальний ефект (СПЕ) усереднений на популяції: $\mathrm{b} \equiv \mathrm{E}($ b популяиіï $) \equiv \mathrm{E}(b$ вибірки $)$.

Якщо у нас $\epsilon$ множина ковариат $\mathbf{x}$, частина $з$ яких може вимірювати складові програми, тоді ми можемо ідентифікувати СПЕ в залежності від $\mathbf{x}: \mathrm{E}(b \mid \mathbf{x})$. Необхідними до вектора незалежних змінних $\mathbf{x}$ як валідних прокси-змінних до с є 2 умови надлишковості $\mathbf{x}$ i $\mathbf{c}$.

1. Вектор $\mathbf{x} \epsilon$ надлишковим за наявних векторів $w$ i $\mathbf{c}:$

$$
\mathrm{E}(y \mid w, \mathbf{c}, \mathbf{x})=\mathrm{E}(y \mid w, \mathbf{c})=a+b w
$$


2. В двох перших моментах $w \mathbf{c}$ надлишкове за присутності х:

(i) $\mathrm{E}(w \mid \mathbf{c}, \mathbf{x})=\mathrm{E}(w \mid \mathbf{x})$;

(ii) $\operatorname{Var}(w \mid \mathbf{c}, \mathbf{x})=\operatorname{Var}(w \mid \mathbf{x})$

Wooldridge, J.M. (2004) показав (ф.3.1), що за таких умов СПЕ $w$ на у незміщено оцінюється як [9]:

$$
\mathrm{C} \Pi \mathrm{E}=\mathrm{E}\{[w-\mu(\mathbf{x})] y / w(\mathbf{x})\},
$$

де $\mu(\mathbf{x})$ i $\mathrm{w}(\mathbf{x})$ відповідно середне значення і дисперсія вектора $w$.

Є кілька категорій АТЕ оцінщиків (10) за виконання умов (8) i (9). Перша використовує пропозицію «надлишковості» вектора $w$ за присутності ковариат $\mathbf{x}$. Фактично техніки сполучні 3 вирішенням проблеми пропущених змінних за допомогою прокси- змінних, і за особливих умов спрощуються до OLS регресії з багатьма контрольними когортами. Друга категорія оцінщиків грунтується на використанні інструментальних змінних (IV), які є надлишковими в рівняннях, які описують АTE (у нашому випадку з залежною змінною «час виникнення CA 3 моменту початку спостереження»), проте мають унікальний вплив в рівняннях, які описують вірогідність призначення ПП (участі у програмі). Специфікація IV оцінщика залежить від передбаченої функціональної форми зв’язку між НГ і залежною змінною.

Ми використали техніку першої категорії з причини відсутності надійних інструментальних змінних.

Аналітичні техніки цієї категорії базуються на пропозиції Розенбаума i Рубіна [8], яка відома як ігнорування змінної призначення програми (ignorability of treatment) за спостережених ковариат х, а саме:

$$
\text { (a) } \mathrm{E}\left(\mathrm{y}_{0} \mid \mathbf{x}, w\right)=\mathrm{E}\left(\mathrm{y}_{0} \mid \mathrm{x}\right) ; \text { (b) } \mathrm{E}\left(\mathrm{y}_{1} \mid \mathbf{x}, w\right)=\mathrm{E}\left(\mathrm{y}_{1} \mid \mathbf{x}\right)
$$

де $\mathrm{y}_{0}$ та $\mathrm{y}_{1}-$ значення залежної змінної у дітей контрольної та експериментальної (з призначенням програми) когорт. Ідея пропозиції (11) наступна: якщо у нас $є$ достатньо інформації в $\mathbf{x}$ про призначення програми, то середні значення залежної змінної можуть не залежати від факту призначення ПР за умовою включення $\mathbf{x}$ в модель. Спрощено, навіть якщо уо та у корельовані 3 , ця кореляція пояснюється $\mathbf{x}$ і вона втрачається при врахуванні х в моделі.

Одним 3 ефективних методів оцінки АТЕ за виконання (11) є метод контрольних функцій. А саме, контрольні функції від $\mathbf{x}(\mathrm{g}(\mathbf{x}))$ добавляють в регресію $y$ на $1, w$ для контролю порушення рандомізації призначення програми, а саме:

$$
\mathrm{E}(\mathrm{y} \mid \mathbf{x}, w)=\mu_{0}+\alpha w+\mathrm{g}_{0}(\mathbf{x})+w\left[\mathrm{~g}_{1}(\mathbf{x})-\mathrm{g}_{0}(\mathbf{x})\right]
$$

Коефіцієнт $\alpha$ при індикаторі призначення програми $w$ оцінює АТЕ. Якщо контрольні функції лінійні в $\mathbf{x}$, то вираз (12) спрощується до

$$
\mathrm{E}(\mathrm{y} \mid \mathbf{x}, w)=\mu_{0}+\alpha w+\beta_{0} \mathbf{x}+w[\mathbf{x}-\ddot{\mathbf{x}}] \theta
$$

3 нормалізацією значень ковариат $\mathbf{x}$ відносно вектора середніх $\ddot{\mathbf{x}}$. Таке децентрування необхідно для збереження незміщеності оцінки $\alpha$ (АТЕ), яка зливається $3 w \ddot{\mathbf{x}} \theta$ за відсутності центрування.

У ЛП моделей (1-3) АТЕ представлений як:

$$
b[18]^{*} \text { Treatment }+b[20]^{*} \text { Treatment* } b_{j}+b_{j}
$$

Головним параметром тестування АТЕ $є$ коефіцієнт «beta», ідентифікація якого від зміщень внаслідок порушення рандомізації призначення програми забезпечується включенням компоненти beta2* Treatment* $\mathbf{b}_{\mathrm{j}}$, яка відповідає контрольній функції $w[\mathbf{x}-\ddot{\mathbf{x}}] \theta$ в (ф.13). $b_{j}$ виражає індивідуальний ефект школяра, який децентровано приписанням функції генерації його апріорних значень нормальному закону 3 нульовим середнім (b[j] dnorm(0, tau) в тексті програмного коду). Фактично індивідуальний ефект вбирає в себе усі можливі фіксовані ефекти, зокрема не спостережені ознаки, являючись, таким чином, потужною прокси- змінною для незміщеного тестування ефекту призначення ПП. Несуттєвість коефіцієнта «beta2» свідчить про відсутність зміщень оцінки АТЕ внаслідок порушення рандомізації призначення ПП.

Отримання маргінальних змін ризику виникнення СA

$€$ два варіанта оцінки маргінальної зміни ризику виникнення $C A$ внаслідок участі в ПП. Перший полягає в оцінці базового індивідуального ризику $h_{0}(t)_{i}$ за $\phi .1$ та ф.4 відповідно моделям (1) та (2) з ЛП, що включає лише константу, а у випадку моделі (3) константу та фрейлті. Модифіковані участю у ПП значення ризику отримуються відповідно включенням змінних АТЕ (ф.14). Різниця між індивідуальними базовими та очікуваними значеннями ризику за участі у ПП і становлять маргінальний інкремент ризику виникнення СА.

Другий варіант полягає у тому, що за оціненим вектором коефіцієнтів b моделі ми розраховуємо очікувані значення вірогідності виникнення СА за участі у ПП і без такої для кожного школяра $i: \hat{\pi}_{\Pi п+i}$ та $\hat{\pi}_{\Pi \Pi-i}$ відповідно.

Зміна ризику $\Delta \pi_{\mathrm{i}}$ для кожного школяра $i$ отримується як різниця $\hat{\pi}_{\Pi \Pi-i}$ та $\hat{\pi}_{\Pi \Pi+i}$ :

$$
\Delta \pi_{\mathrm{i}}=\hat{\pi}_{\Pi \Pi-i}-\hat{\pi}_{\Pi \Pi+i}
$$

Ми обрали саме другий варіант, так як він забезпечує досконалішу стандартизацію включених у дослідження факторів ризику, зокрема року спостереження, класу, віку дитини, наявності специфічних факторів ризику.

Склад предикторів моделі визначався їх апріорним модифікуючим впливом на виникнення СА, а саме:

- вік (клас) виникнення СА;

- стать школяра;

- фактори ризику виникнення спазму акомодації:

- обтяжена спадковість

- наявність «миготливого тіку» в анамнезі

- часті головні болі (1-2 рази на тиждень)

- струс головного мозку в анамнезі

- потемніння в очах в анамнезі 
- синдром «сухого ока»

- наявність сколіозу, кіфозу, травм шийного відділу хребта

- наявність тонзиліту

- тривалість нічного сну менше 8 год.

- щоденна безперервна робота за комп'ютером

більше 2 год.

- щоденний активний відпочинок (прогулянки но свіжому повітрі більше 2 год.)

квартирі

- проживання сім’ї у гуртожитку або найманій

- наявність стресових ситуацій

- кількість факторів ризику у школяра

- участь у ПП.

\section{Реалізація та програмне забезпечення}

Потужнім сучасним драйвером імплементації ієрархічних мікст моделей, до яких відноситься наша модельна структура, є МСМС алгоритми. Ми обрали найбільш відпрацьований і потужній Гіббс семплер (Gibbs sampler). Аналітичний програмний модуль написано мовою WinBUGS, що $є$ абревіатурою виразу Bayesian inference using Gibbs (software). Розрахунок параметрів моделей здійснювався в середовищі пакету WinBUGS версії 1.4. Попередня підготовка даних, а також дослідження конвергенції в ланцюгах Маркова здійснена в середовищі математичної аналітичної системи $\mathrm{R}$ версії 3.4.0 на основі пакету CODA.

\section{Результати дослідження та їх обговорення}

\section{Оиінка едекту участі в ПП}

Перш за все нас цікавить ефект участі у ПП, так як дизайн дослідження побудований саме для досягнення мети роботи, яка грунтується на оцінці клінічної та економічної ефективності ПП. Усі інші ефекти мають значно менший зміст і можливо скошене оцінювання, так як всі інші змінні введені лише для незміщеного оцінювання очікуваних змін ризику виникнення СА внаслідок участі у ПП. Слід звернути увагу, що найбільш валідно ефект участі у ПП оцінюється фрейлті моделлю (3), яка реалізує АТЕ конструкцію.

Як випливає 3 результатів моделювання, ефект ПП $\epsilon$ високо достовірний. Жоден 3 постеріорних довірчих інтервалів не включає нуль. Всі оцінки інтервалу негативні значення, тобто участь у ПП зменшує ризик розвитку СА. Іншими словами, періоди часу до виникнення СА подовжуються. Значно вираженішим є ефект участі у ПП за третьої моделі з медіанним значенням -2,4340, тобто iз зменшенням річного ризику на $0,72 \%\{1+\mathrm{EXP}(-4,83$ $-2,434)\}^{-1}-(1+\operatorname{EXP}(-4,83))^{-1}$. I саме ця оцінка $\epsilon$ найбільш змістовною. По-перше, використання фрейлті компенсує штучне зменшення регресійних ефектів, ефекти факторів ризику набувають більш доречний позитивний напрямок, тоді як негативність цих ефектів за базової моделі обумовлюється насамперед змішувальним динамічним ефектом (більш чутливі школярі з фактором ризику уже розвинули СА до початку спостереження, а ті, що вистояли, мають низьку чутливість, а отже, від'ємні ефекти); по-друге, здійснюється поправка на динамічне накопичення менш чутливих до розвитку СА дітей; по-третє, реалізується АТЕ з використанням контрольних функцій за участю фрейлті; в четвертих, контролюється неспівставність контрольної та основної когорт дітей за наявністю факторів ризику.

Про суттєві переваги інформативності третьої моделі свідчить коефіцієнт девіації очікуваних i спостережених проміжків (параметр Dv). Останній отримується як від'ємне подвоєне значення суми логарифмів індивідуальних оцінок правдоподібності і в програмному скрипті представлено як

Dv $<--2 * \operatorname{sum}(\mathrm{LL}[])$.

Спостерігається різке падіння значення параметр Dv саме за третьої моделі $(866,3 ; 867,3$; та 526,6 відповідно моделям).

Важливою $є$ конвергенція оцінок ефекту участі у ПП, значення яких на 20 тис. ітераціях семплера Гіббса 3 кроком 20 (тобто зображене кожне 20 послідовне згачення семплеру) показані на рис. 2 (моделі А - базова, Б 3 фракцією нечутливих, В - фрейлті 3 фракцією нечутливих). Простежується досить гарна конвергенція семплеру з стабільноими медіанами та гомоскедастичністю (рівним розсіянням окремих значень на всьому діапазоні ітерацій). Відмічається дещо вища варіація значень за третьою моделлю.

Найважливішим параметром ATE, що корегує зміщення ефекту участі у ПП, є параметр $\mathrm{b}[20]$, який відповідає контрольній функції $w[\mathbf{x}-\ddot{\mathbf{x}}] \theta$ в (ф.13). Цей параметр виправляє i оцінює зміщення оцінки АТЕ внаслідок гетерогенності контрольної та експериментальної когорт.

Значення $2,5 \% \quad(0,05)$ і $97,5 \% \quad(0,95)$ центилів аапостеріорного розподілу оцінок зміщення (параметр $\mathrm{b}[20])$ випливає відсутність достовірного ефекту, так як 0 знаходиться в межах 95\% інтервалу [-2,1520; 0,1847], хоч і досить далеко від його центру. Широкий, хоч і скошений відносно 0 діапазон довірчого 95\% інтервалу є доказом надлишковості ефекту і його малої інформативності. Таким чином, оцінка ефекту АТЕ $€$ незміщеною і за відсутності поправочного ефекту. 3 огляду на це ефект участі у ПП є досить робастним для інтерпретації в моделях (1) та (2).

Початок участі у програмі має суттєве значення (параметр b[17]), а саме кожний наступний рік зменшує ефективність ПП. Продемонструємо на зміні виживаності на першому році за ф.(4.1) за базовою моделлю при призначенні в першому та другому класах. Так, на першому році $(\mathrm{t}=1)$ виживаність при початку участі у ПП в першому класі складає $[1+\exp (-4.83+0.66)]^{-1}=0.9847829$, а при початку в другому класі $[1+\exp (-4.83+1.32)]^{-1}=$ 0.970971 з різницею 0.01381191 . 

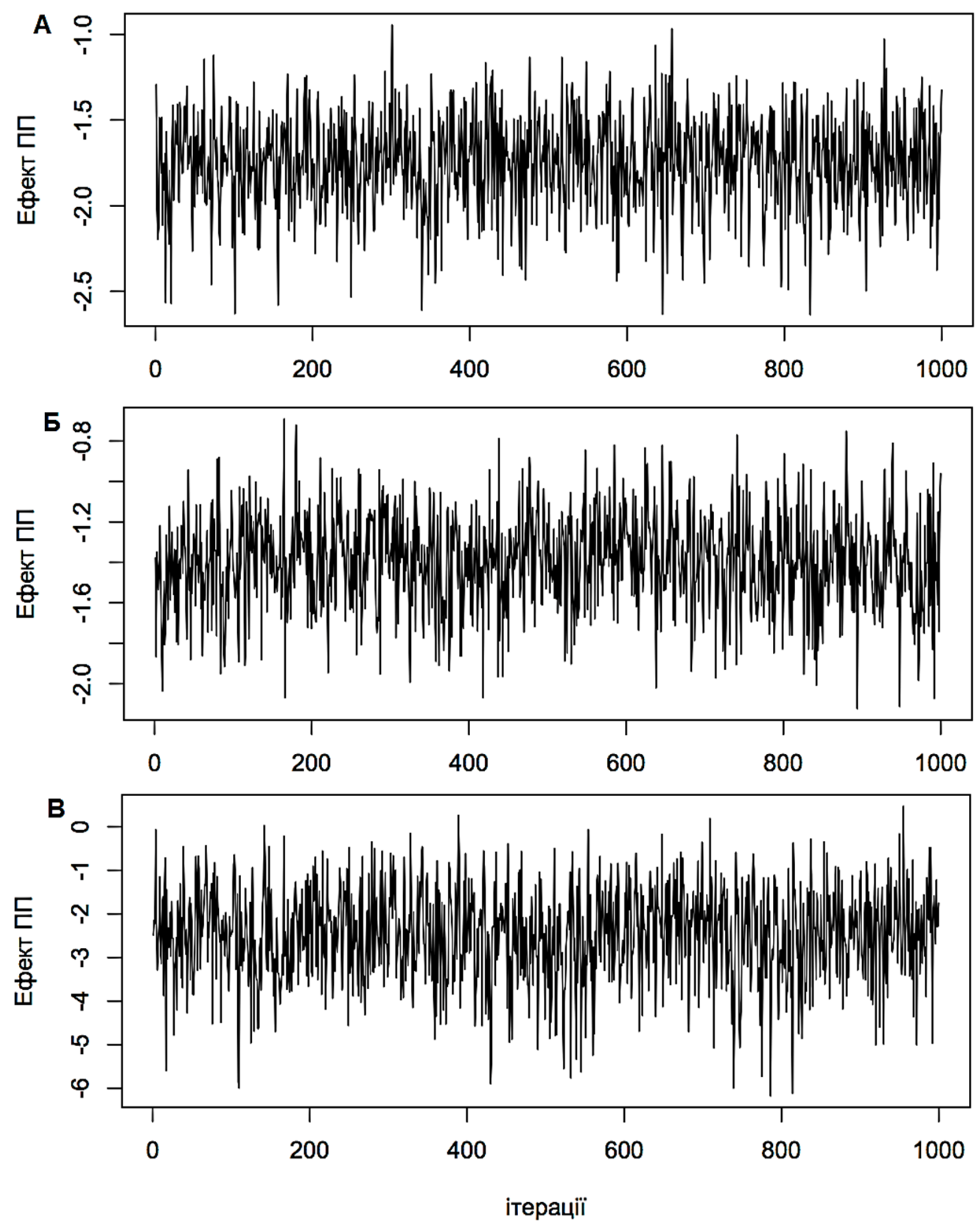

Рис. 2. Оцінка ефекту програми профілактики спазму акомодації на МСМС ітераціях алгоритму Гіббса (моделі $\mathbf{A}$ - базова, $\mathbf{~}-3$ фракцією нечутливих, $\mathbf{B}$ фрейлті з фракцією нечутливих).

Наступним важливим для ідентифікації ефекту участі у ПП є розподіл фрейлті. По-перше, важливо, що із центилів апостеріорних розподілів оцінок сигмального відхилення розподілу фрейлті (параметр sig.u) випливає достовірна відмінінсть від нуля, так як 0 знаходиться поза межами $95 \%$ інтервалу $[2,081 ; 4,173] \quad 3$ медіанним значенням 2,851. По-друге, сам розподіл фрейлті має виражений унімодальний розподіл, що відповідає гомогенності когорт за значеннями фрейлті, про що свідчить гістограма розподілу (рис. 3). Розподіл достовірно відрізняється від нормального (статистика D тесту Колмогорова-Смирнова $=0,333 \quad$ з $<<0,001)$ за рахунок ексцесу, коефіцієнт якого значно перевищує 3 i вказує на свічкоподібний розподіл значень фрейлті серед школярів з типовими значеннями, що лежать в інтервалі $[-1 ;+1]$. Хвости роподілу не виражені і крайні значення вкладаються в проміжок медіана $\pm 2,5$ сигми. Таким чином, нетипові значення відсутні, що уможливлює генерацію значень фрейлті нормальним законом, як і було здійснено в програмному скрипті. Таким чином, гетерогенних груп за фрейлті не виявлено, що значно спрощує моделювання та інтерпретацію результатів, зокрема очікуваних значень ризиків за всіма трьома моделями. Якби була виявлена кластеризація школярів за фрейлті, результати моделей (1) та (2), що не враховують фрейлті було б важко інтерпретувати. 


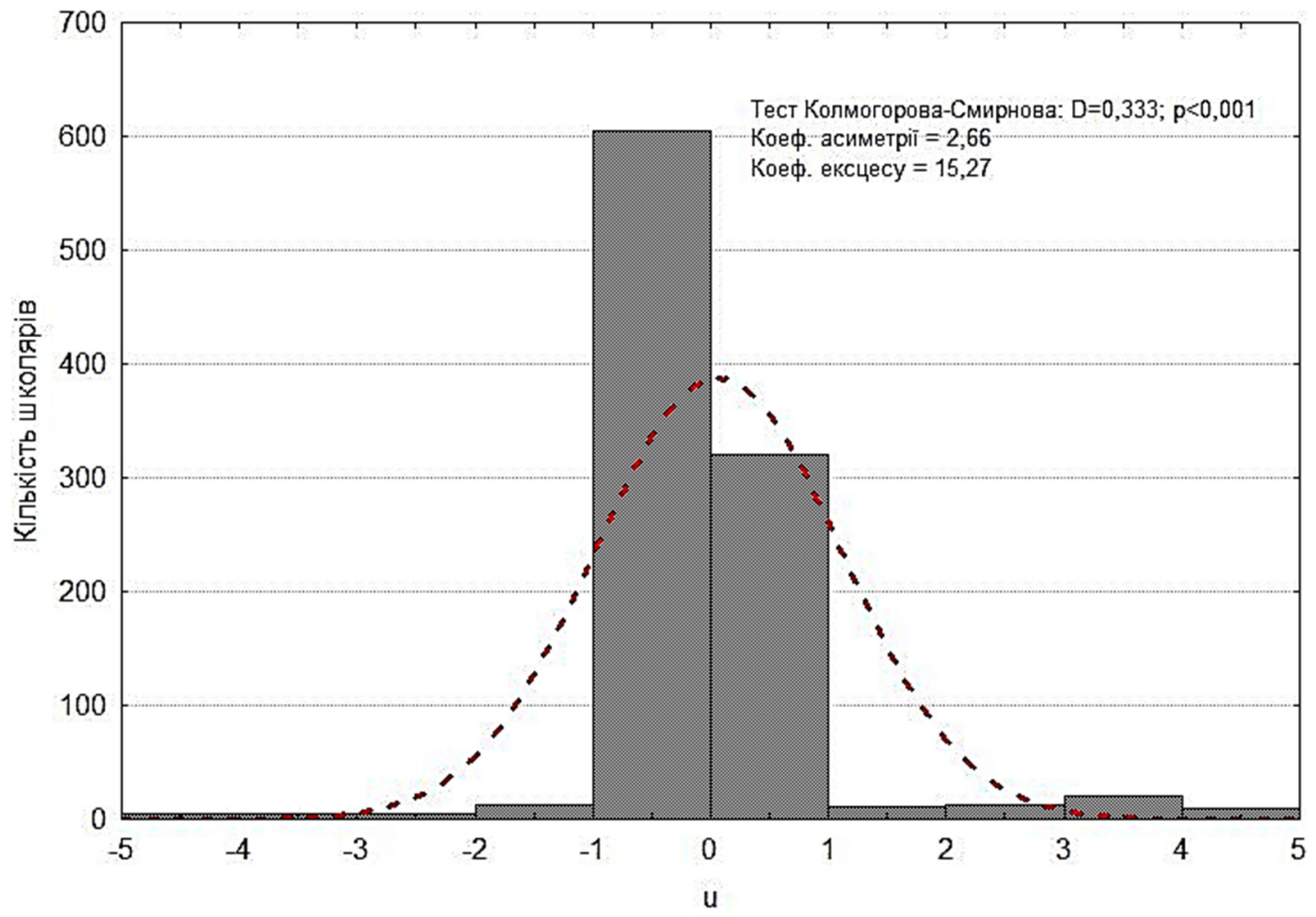

Рис. 3. Гістограма розподілу фрейлті (u) школярів

Ще однією проблемою ідентифікації та незміщеного оцінювання ефекту участі в ПП $\epsilon$ спостережена присутність достовірного зв'язку між кількістю факторів ризику та участю у ПР, що уможливлює присутність змішувального ефекту кількості факторів ризику на ефект ПР через порушення рандомізації участі у ПР. За даними таблиці розподіли кількості факторів ризику суттєво відрізняються по групам контролю та основній, $\chi^{2}(9)=19 ; \mathrm{p}=0.025$. Ми включили корекцію зміщення через параметр b[19]. Iз центилів апостеріорних розподілів оцінок параметру випливає відсутність достовірного змішувального ефекту, так як 0 знаходиться в межах 95\% інтервалу [-0,5128; $0,6474]$ з медіанним значенням близьким до нуля, а саме 0,0464 . Отже, суттєва різниця по групам контролю та основній щодо факторів ризику не призводить до суттєвих зміщень оцінки ефекту участі у ПП, остання $\epsilon$ незміщеною і за відсутності поправочного ефекту. 3 огляду на це ефект участі у ПП теж не зміщений різницею по групам контролю та основній щодо факторів ризику, і $є$ робастним для інтерпретації в моделях (1) та (2).

Оиінка ризиків розвитку $C A$

Перш за все, слід відмітити відсутність фракції нечутливих, так як відповідний параметр Nonsensitives має апостеріорний розподіл з фактично нульовою медіаною $(0,4 \%)$ з інтервалом $[0 \% ; 2,3 \%]$ за моделі (2) і медіаною $0 \%$ та інтервалом $[0 \% ; 1,5 \%]$ за моделі (3). Більш того, не має кластеризації ризику, що передбачено моделлю (2), а саме за якою вся вибірка розподіляється за латентними групами «вродженого» ризику до розвитку $\mathrm{CA}\left(\mathrm{G}_{0}, \ldots, \mathrm{G}_{\mathrm{K}}\right)$. Дані не підтверджують такої групової сегрегації чутливості. Саме тому i інформативність моделі (2) не покращилась порівняно з такою базової - параметр Dv мав відповідно значення 866,3 та 867,3. Проте, як було зазначено, індивідуальні чутливості (фрейлті) мають чітко виражений унімодальний розподіл, врахування якого різко покращує інформативність моделі, корегує ряд параметрів (ефектів) як за величиною, так і за напрямком (перш за все регресійні ефекти факторів ризику), тобто модель (3) краще підтверджується даними i логікою процесу формування СА.

Ми розглянули основні динамічні профілі очікуваного ризику, які утворені факторами ризику та участю у ПП, а саме:

- За відсутності факторів ризику і без участі в ПП

- За відсутності факторів ризику і за участі в ПП

- 3 присутніми факторами ризику і без участі в ПП

- 3 присутніми факторами ризику і без участі в ПП

Як видно 3 рис. 4 динамічні профілі майже не залежать від моделі і мають спільні закономірності, а саме:

- участь у ПП гарантує зменшення очікуваного ризику незалежно від наявності факторів ризику;

- участь у ПП більш ефективно зменшує ризики у школярів 3 наявністю факторів ризику;

- за наявності факторів ризику динаміка ризику має регресивний характер, що є наслідком зміщення внаслідок селекції за чутливістю, поясненою вище; наявність регресивної динаміки за третьої моделі пояснюється невключенням фрейлті до складу лінійних предикторів профілів моделі (3) для співставності ризиків за моделями;

- рівні ризиків вищі за наявності факторів ризику. 

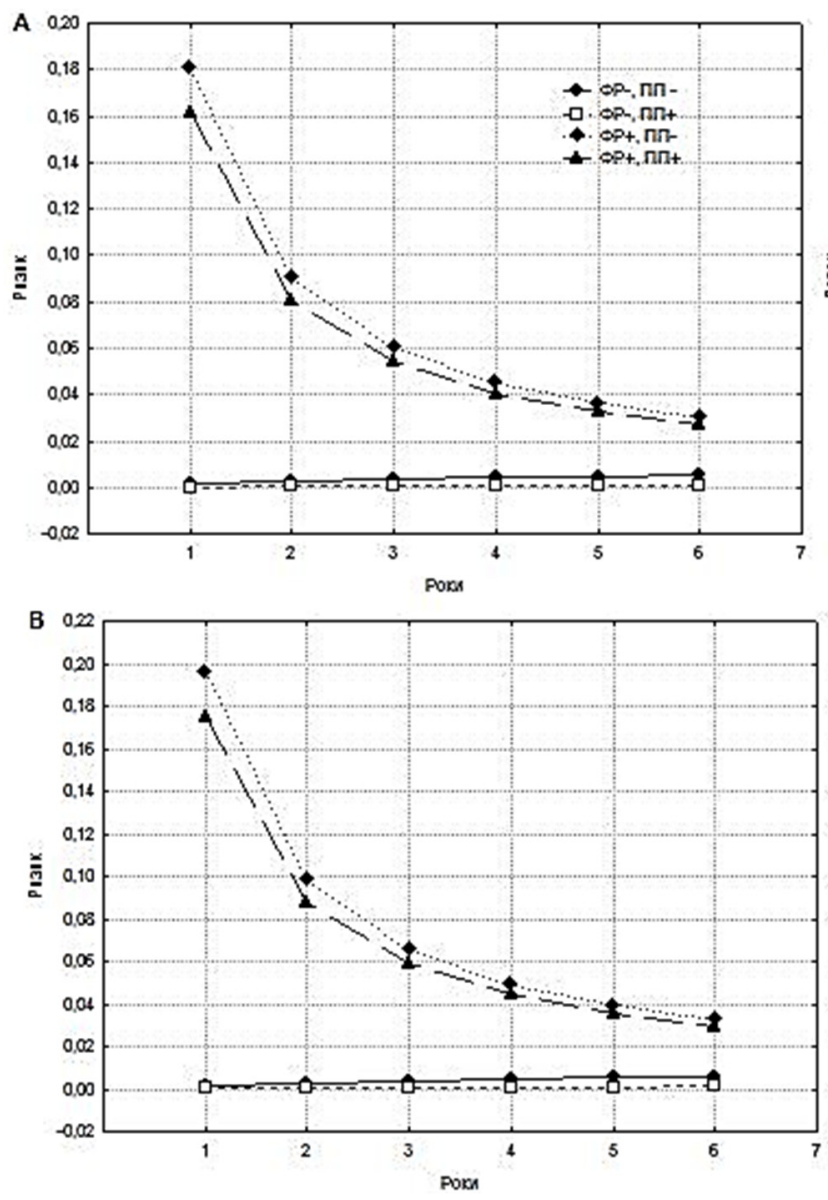

Індивідуальні маргінальні значення зменшення ризику (масив розміром 1031) внаслідок участі у ПП розраховані за ф. (15). Їх розподіли за моделями зображені на рис. 5. Розподіли фактично ідентичні. Переважна більшість значень знаходиться в інтервалі 0-0,1, тобто до $10 \%$ зменшення ризику. Середні значення розподілів дещо різняться і складають 0,037496; 0,0250002; та 0,0408114 відповідно за моделей (1), (2), (3). Тобто, середньорічне маргінальне очікуване зменшення ризику виникнення СА внаслідок участі у ПП складало 3,75\%, 2,50\%, та 4,08\%.

Для вивчення економічної ефективності ПП ми використали індивідуальні маргінальні значення зменшення ризику, отримані за третьою моделлю, яка

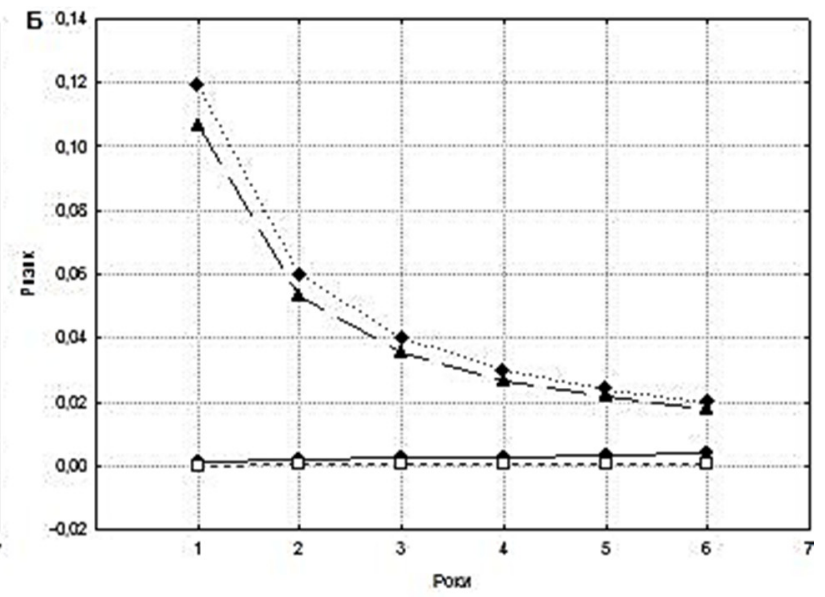

\author{
Умовні позначення: \\ ФР- фактори ризику змодельовані як відсутні \\ ФР+ фактори ризику змодельовані як присутні \\ ПП - участь у ПП змодельована як відсутня \\ ПП + участь у ПП змодельована як присутня \\ моделі: \\ A - базова \\ Б - $з$ фракцією нечутливих \\ В - фрейлті з фракцією нечутливих
}

\section{Рис. 4. Динаміка очікуваних ризиків розвитку СА за роками від початку спостереження} (1 - в той же рік)

дає найменш зміщену оцінку ризикам внаслідок удосконаленої модифікації. Важливим $є$ дослідження зв'язку між індивідуальними маргінальними значеннями зменшення ризику та індивідуальною природженою чутливістю школярів, остання описується фрейлті. На рис. 6 зображена діаграма розподілу очікуваних значень зменшення ризику $(\Delta h)$ внаслідок участі у ПП в залежності від розподілу фрейлті (u). Дещо кращий клінічий ефект ПП по зниженню маргінальних ризиків досягається за низької природженої чутливості до розвитку СА. Проте найбільш виразні амплітуди зменшення ризику були спостережені для типових (медіанних) значень фрейлті. 

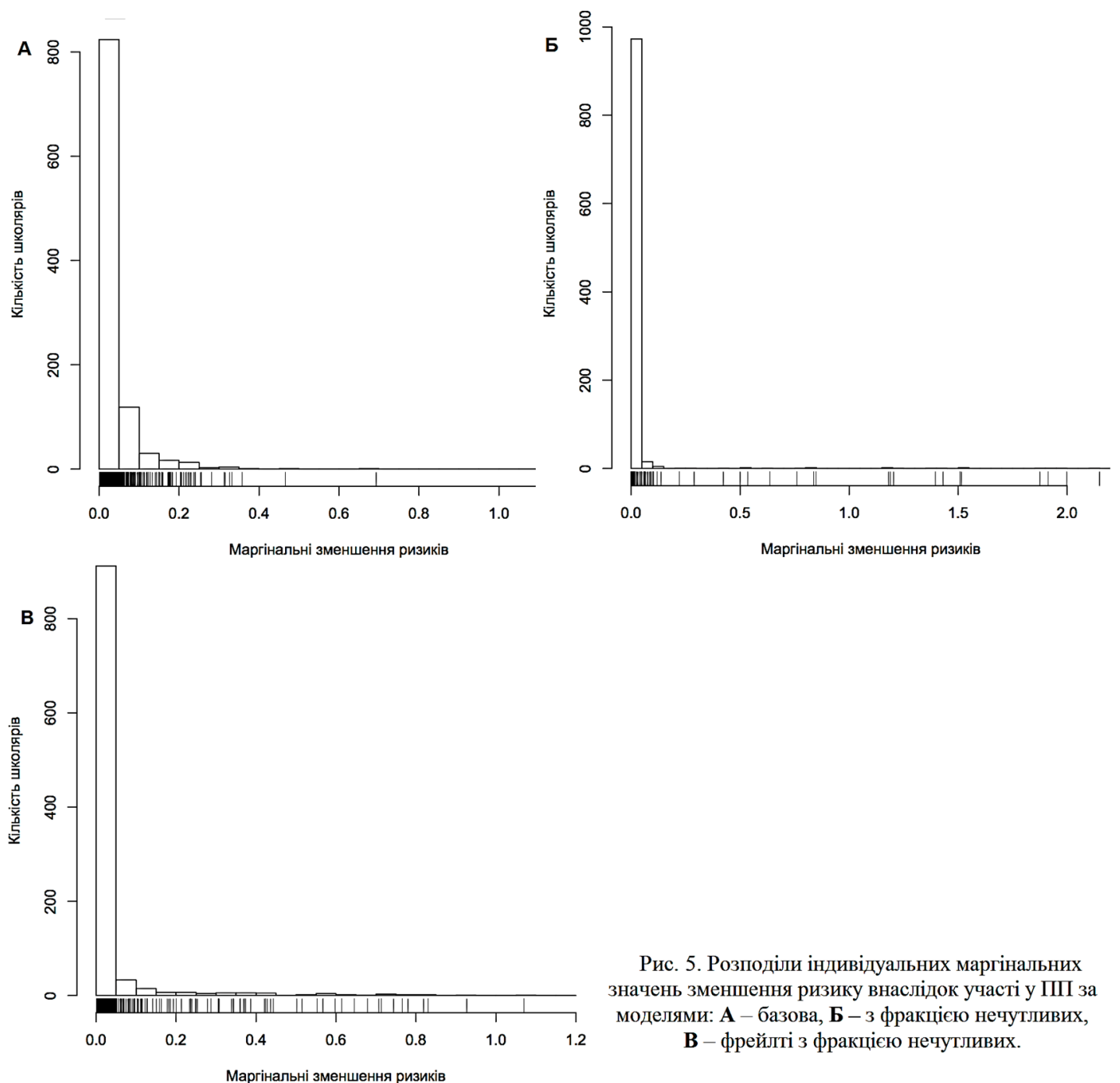

Рис. 5. Розподіли індивідуальних маргінальних значень зменшення ризику внаслідок участі у ПП за моделями: А - базова, $\mathbf{5}-3$ фракцією нечутливих, В - фрейлті з фракцією нечутливих.

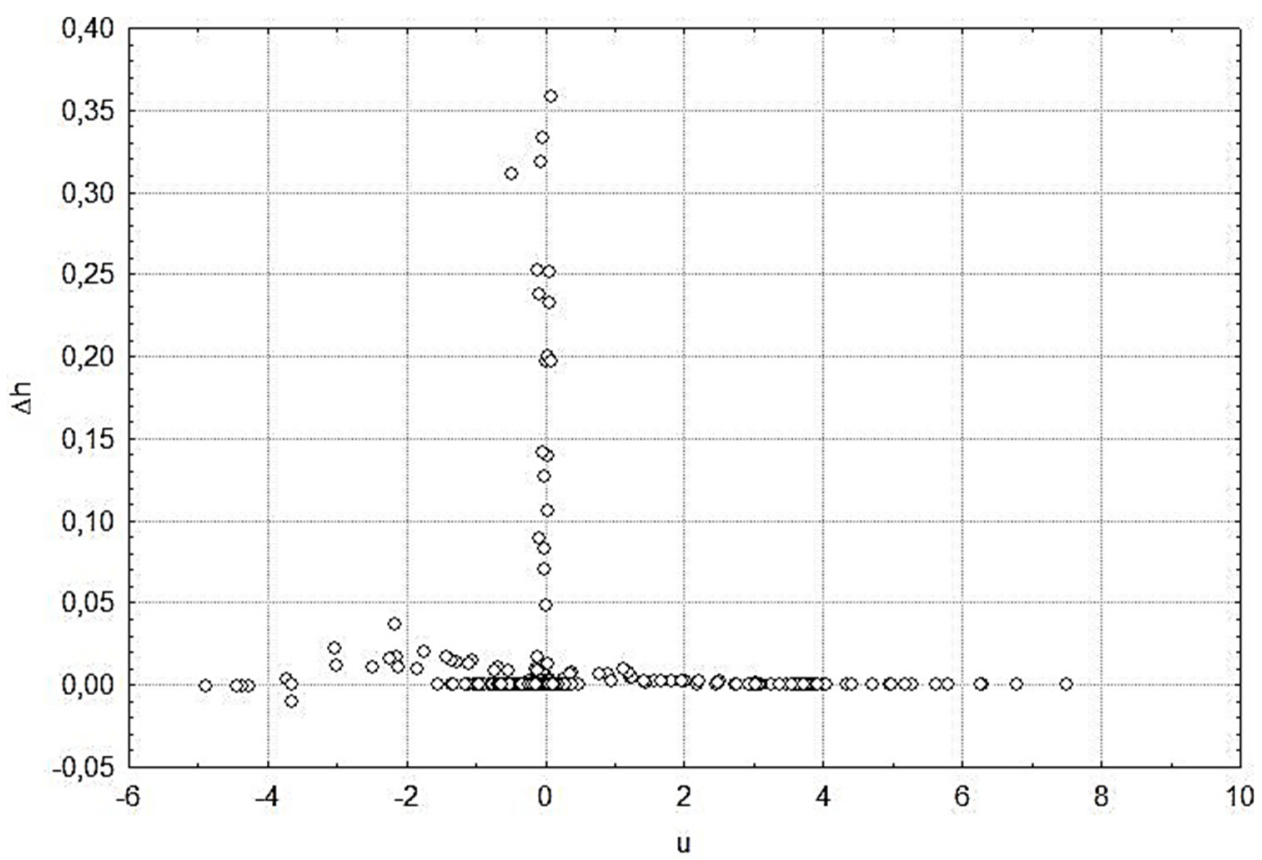

Рис. 6. Діаграма розподілу очікуваних значень зменшення ризику $(\Delta h)$ внаслідок участі у ПП в залежності від розподілу фрейлті (u) 


\section{Висновки}

Оцінка ефективностті програм профілактики розвитку спазму акомодації утруднена великим і мінливим латентним періодом, супутніми впливовими факторами, кластеризацією школярів по школам, класам, викладачам. Оцінка ефективності за експериментальним фреймом може бути зміщеною через скошеність призначення виду програми профілактики, а також внаслідок змішувального ефекту множини факторів, рівні яких не контролюються дизайном, ба навіть невідомі.

Ми оцінили можливі зміщення та їх обсяг на реальному панельному дизайні 3 використанням семипараметричної моделі Кокса, фрейлті моделі, фрейлті моделі 3 фракцією нечутливих. Оцінка ефективності програми вирівнювалась на притаманне зміщення внаслідок скошеності призначення через СПЕ конструкцію.

Середнє річне зменшення ризиків СА внаслідок участі у ПП за різними моделями складало $3,75 \%, 2,50 \%$, та 4,08\%. Причому ефект відтворений незалежно від моменту початку участі у ПП.

Початок участі у програмі має суттєве значення, а саме кожний наступний рік достовірно зменшує ефективність ПП. Так, на першому році виживаність при початку участі у ПП в першому класі складає 0.985 , а при початку в другому класі 0.971 .

Спостережена відсутність фракції нечутливих, так як відповідний параметр має апостеріорний розподіл 3 фактично нульовою медіаною $(0,4 \%)$ з інтервалом [0\%; $2,3 \%$ ] за моделі (2) і медіаною 0\% та інтервалом [0\%; $1,5 \%]$ за моделі (3). Більш того, не має кластеризації ризику, що передбачено моделлю (2), а саме за якою вся вибірка розподіляється за латентними групами «вродженого» ризику до розвитку $\mathrm{CA}\left(\mathrm{G}_{0}, \ldots, \mathrm{G}_{\mathrm{K}}\right)$. Дані не підтверджують такої групової сегрегації чутливості.

Вивчення динамічних профілів очікуваного ризику свідчить, що участь у розширеній програмі профілактики більш ефективно зменшує ризики у школярів 3 наявністю факторів ризику.

Середньорічне маргінальне очікуване зменшення ризику виникнення СА внаслідок участі у ПП складало 3,75\%, 2,50\%, та 4,08\% за трьома моделями відповідно. Дещо кращий клінічий ефект ПП по зниженню маргінальних ризиків досягається за низької природженої чутливості до розвитку СА. Проте найбільш виразні амплітуди зменшення ризику були спостережені для типових (медіанних) значень фрейлті.

\section{Література}

1. Bennett $S$ (1983). Log-logistic regression models for survival data. Applied Statistics, 32, 165-71.

2. Br"uderl J, Diekmann A (1995). The log-logistic rate model: Two generalizations with an application to demographic data. Sociological Methods \& Research, 24, 158-86.

3. Chen $M-H$, Ibrahim J, Sinha D (2001). A new Bayesian model for survival data with a surviving fraction. Journal of the American Statistical Association, 94, 909-19.

4. Chen $M-H$, Ibrahim J, Sinha D (2002) Bayesian inference for multivariate survival data with a cure fraction. Journal of Multivariate Analysis, 80, 101-26.

5. Abbring $J$, van den Berg G (2003). The identifiability of the mixed proportional hazards competing risks model. Journal Royal Statistical Society: Series B, 65, 701-10.

6. Lancaster $T$ (1990). The econometric analysis of transition data. Cambridge:Cambridge University Press.

7. Abbring $J$, van den Berg G (2007) The unobserved heterogeneity distribution in duration analysis. Biometrika, 94, 87-99.

8. Rozenbaum, P.R., and Rubin D.B. (1983). The Central Role of the Propensity Score in Observational Studies for Casual Effects. Biometrika, 70, 41-45.

9. Wooldridge, J.M. (2004), "Estimating average partial effects under conditional moment independence assumptions", the Institute for fiscal studies, Department of economics, ucl cemmap working paper cwp 03/04, 38p.

Дата надходження рукопису до редакиї: 27.09.2019 p. 


\section{Обоснование и идентификация моделей оценки эффекта программ профилактики развития спазма аккомодации}

Старинеи Н.А., Очередько А.Н.

Цель - обоснование и идентификация моделей оценки эффекта программ профилактики развития спазма аккомодации на базе современных аналитических методов и дизайнов.

Материалы и методы. Материалами стали разработанные нами программы исследования, общий объем выборки составил 1115 школьников. Использован панельный гниздований блочный дизайн. Серийным методом изучены первичные случаи возникновения нарушений аккомодации у школьников вместе с медикоорганизационными и популяционными обусловливающих факторов в течение 2014-2018 годов с участием в стандартной и расширенной программах профилактики. Аналитические методы охватывали семипараметрическую модель Кокса, фрейлти модель, фрейлти модель с фракцией нечувствительных.

Результаты засвидетельствовали отсутствие прослойки школьников, нечувствительных к развитию спазма аккомодации (СА). Другая идентификация формы включала индивидуальный распределение чувствительности (фрейлти модель), однозначно поддержана данными. Итак, поддерживается гипотеза о наличии индивидуальной чувствительности к развитию СА и последующей миопии. Установлено, что участие в программе профилактики (ПП) существенно уменьшает риск возникновения СА независимо от присутствия приобретенной чувствительности (факторов риска) и врожденной (фрейлти). Вывод робастный по трем моделям. Поэтому ЧП целесообразна для назначения каждому школьнику безоговорочно относительно индивидуальных признаков. Среднее годовое уменьшение рисков СА в результате участия в ЧП по различным моделям составляло $3,75 \%, 2,50 \%$, и 4,08\%. Причем эффект воспроизведен независимо от момента начала участия в ПП.

\section{Substantiation and identification of models for assessing the effect of programs of prevention of the development of spasm of accommodation}

Starynets M.A., Ocheredko O.M.

The purpose is to substantiate and identify models for assessing the effect of programs for the prevention of accommodation spasm on the basis of modern analytical methods and designs.

Materials and methods. Our research programs have been developed, with a total sample size of 1,115 students. Used panel nested block design. The primary case study investigated primary cases of maladaptation in schoolchildren, along with health, organizational and population conditioning factors during 2014-2018, through participation in standard and extended prevention programs. Analytical methods included a seven-parameter Cox model, a fratil model, a fratil model with an insensitive fraction.

The results indicated the absence of a layer of schoolchildren insensitive to the development of accommodation spasm (AS). Other identification of the form included an individual distribution of sensitivities (the Fralty model), which is uniquely supported by the data. Therefore, the hypothesis of the presence of individual sensitivity to the development of AS and subsequent myopia is supported. Participation in a prevention program (PP) was found to significantly reduce the risk of AS regardless of the presence of acquired sensitivity (risk factors) and congenital (freilty). The conclusion is robust by three models. Therefore, PP is appropriate for assigning each student unconditionally for individual characteristics. The average annual reduction in AS risk due to participation in PP under different models was $3.75 \%, 2.50 \%$, and $4.08 \%$. Moreover, the effect is reproduced regardless of the moment of participation in the PP. 